Article

\title{
Following Fatigue, Feeling Fatigue: A Reflexive Ethnography of Emotion
}

\author{
Mirjam Wajsberg \\ Department of Geography, Planning and Environment, Radboud University, 6525 XZ Nijmegen, The Netherlands; \\ E-Mail: m.wajsberg@fm.ru.nl
}

Submitted: 24 June 2020 | Accepted: 28 September 2020 | Published: 19 November 2020

\begin{abstract}
This article takes the emotion of fatigue both as its analytical object as well as a methodological tool to engage in a reflexive ethnography, to question the categorical borders of researcher, researched and the field, in the politicised context of migration studies. I do so by drawing on ethnographic material collected during my fieldwork between Athens, Hamburg and Copenhagen in 2019-2020. This article's theoretical and conceptual framing is informed by feminist scholarship on emotions, as well as decolonial scholarship in migration studies. By bringing these theoretical threads into the conversation, I study the different qualities of fatigue, amongst others the collective; how fatigue circulates in and through the ethnographic field; and how it shapes relations between refugees, humanitarian aid workers, activists and researchers such as me. Following fatigue across and through its many different instances in this reflexive ethnography of emotions lays bare the uneven emotional geographies that exist and are (re-)produced in the encounters between actors in Europe's migration control field.
\end{abstract}

\section{Keywords}

emotion; fatigue; methodology; migration; migration studies; reflexive ethnography

\section{Issue}

This article is part of the issue "Method as Border: Articulating 'Inclusion/Exclusion' as an Academic Concern in Migration and Border Research in Europe" edited by Kolar Aparna (Radboud University, The Netherlands), Joris Schapendonk (Radboud University, The Netherlands) and Cesar Merlín-Escorza (Radboud University, The Netherlands).

(C) 2020 by the author; licensee Cogitatio (Lisbon, Portugal). This article is licensed under a Creative Commons Attribution 4.0 International License (CC BY).

\section{Introduction}

Following this thematic issue's call to reflect on how methods can reinforce and/or dismantle boundaries within the academic field of migration studies, this article uses the emotion of fatigue as both a methodological tool and an analytical object to argue for an active engagement with emotions in situated ethnographies. This approach has the potential to question and unsettle the roles of researcher and researched, and the idea of the field as a bounded entity more generally.

Conceptually, my approach is inspired by Laliberté and Schurr's (2016) call to (re)-invigorate reflexive practices through a reflexive ethnography of emotions in which the researcher interrogates their own "emotional entanglements" with the 'field.' This enables an enquiry into asymmetrical power relations, questions the ontology of the field and highlights ethical discussions through- out the research process, from ideation and research to writing and dissemination. This call for renewed reflexivity is, I propose, particularly relevant in the field of migration studies because of the increased academic attention to displacement and migration in the wake of the socalled "migration crisis" of 2015 (for discussions of the crisis-framing and particularly the term 'migration crisis' as opposed to other interpretations of and systems in crisis, such as 'asylum reception crisis' or 'political crisis' see Rozakou, 2019, 2020; Tazzioli \& De Genova, 2016). While media and political discourses have contributed to framing the arrival of refugees in terms of a crisis, the field of migration studies has benefited from more funding opportunities for research projects on migration and displacement (Cabot, 2019; Rozakou, 2019). The increased scholarly attention, especially since 2015 , ironically correlates temporally with further restrictions in migration policies in many European countries that have become 
more geared towards the containment, detention and deportation of migrants as well as the criminalisation of humanitarian and logistical aid to refugees (Hänsel, Hess, \& Kasparek, 2019; Tazzioli \& Garelli, 2018). In light of this politicisation of migration and the continuous undermining of asylum rights in European countries, it is important to reflect on the kind of knowledge that migration research produces (see Cabot, 2019; Rozakou, 2019). As Aparna argues:

Rather than a neutral position situated 'outside' the field of asylum, the very status of being a researcher entering into spaces of 'refugee-support' or in dialogue with asylum-seekers/refugees or writing about 'their' condition, implies producing relations that are shaped by power relations. (Aparna, 2020, p. 23)

I argue that this research focus on migration and refugees demands a renewed critical engagement with, and questioning of, the power relations between researchers and the communities and individuals they research. This includes questioning the distribution and extraction of resources in research and enquiring into adverse effects such as the potential reification of boundaries of otherness (see also Rozakou, 2019). In this article, the terms 'migrant' and 'refugee' will be used interchangeably. I thereby follow Cantat (2016), who points out that although the state differentiates and assigns different legal categories to these mobilities, the lived mobility experiences share many commonalities.

To constructively address these issues, I propose to take emotions, specifically fatigue, as the starting point to respond to Laliberté and Schurr's (2016) call for reflexive ethnography to elucidate positionality and power relations and unsettle a tendency for the reproduction of othering categories in migration studies. Fatigue, I suggest, is a constitutive element of the emotional geography in which refugees, humanitarian aid workers, activists and migration researchers move in. I understand fatigue as a prolonged emotional state, a kind of tiredness that is not resolved by, for instance, a good night's rest or leisure activities rather than a temporary or physical state of exhaustion. Psychologists describe this emotional fatigue as a loss of motivation to engage with a repetitive object or action, especially when no significant changes result from the repeated engagement (Hockey, 2013). In the following, I examine my own role in the emotional landscape of fatigue. Thus, fatigue is both the object of analysis and the methodological tool for reflexivity and self-examination. As an object of analysis, I draw on three expressions of fatigue: research fatigue, racial battle fatigue and compassion fatigue. As a methodological approach, I attempt to place myself within the emotional geography of the field and thereby translate some of the messiness and tension of doing fieldwork on migration in the 21st century onto these pages.

This article begins by outlining the theoretical ideas around emotions that have been informed by the body of feminist scholarship on the sociality and politics of emotion, specifically Ahmed's (2014) notion circulating emotions as well as Ngai's (2005) "ugly emotions." Afterward, I highlight three different expressions of fatigue: research fatigue, racial battle fatigue and compassion fatigue. I explore these fatigues through ethnographic scenes based on notes taken during my fieldwork conducted for my PhD research in Athens and Hamburg in 2019-2020. My research engages with different forms of migrant-led activism in urban spaces. The scenes outlined in this article are not verbatim accounts, but rather collages, extensive notes and memories based on interviews, informal conversations and encounters in both cities. Lastly, I discuss how the lens of fatigue highlights the importance of reflexive ethnography to unsettle the categorical borders of researcher and researched, and the so-called field in the context of migration studies.

\section{Thinking Emotions}

My exploration of the emotion of fatigue in its different expressions is informed by feminist scholarship on the sociality of emotions, which emphasises the (re)-productive qualities of emotions in shaping our social and political worlds (see amongst others Berlant, 2004; Bondi, 2005; Lutz \& Abu-Lughod, 1990). I am particularly influenced by Sara Ahmed's (2014) notion of the circulation of emotions. Emotions, Ahmed argues, move within fields of relations where they both acquire meaning, influence meaning and shape interactions. The term 'emotion,' Ahmed points out, already entails the importance of motion (Ahmed, 2014, p. 11). By conceptualising emotions as moving, as circulating, the importance of the spatial relationships between bodies comes into focus. In contrast to other theories of emotion, Ahmed does not make "analytical distinctions between bodily sensation, emotion and thought as if they could be 'experienced' as distinct realms of human 'experience"' (Ahmed, 2014, p. 6). Rather, she emphasises that emotions are located not in the $\mathrm{I} / \mathrm{We}$, but in the social interplay between I/We and Other. Thus, emotions are social and political practices rather than individualised, internal states of being (on Ahmed's theory of emotions see Gorton, 2007).

This approach to emotions enables an investigation into how they are imbued with value through historical and social encounters (Ahmed, 2014; Schmitz \& Ahmed, 2014). Ahmed illustrates this point with the example of the child and the bear: A child meets a bear; the child has never seen a bear before, yet the child is scared and runs away. Even though this is the child's first encounter with a bear, and although the fear experienced by it is bodily and felt instinctively, the child's fear is also produced through the histories, imaginaries and narratives of the bear as a being to be feared that the child has been exposed to previously. Fear is thus not located in either the child or the bear but occurs in the interaction between the child and the bear. The out- 
come of this story, i.e., the child running away from the bear, is however not certain. Ahmed points out that an encounter between either/both a different child and a different bear can lead to another outcome (Ahmed, 2014, p. 7).

This reading of emotions is particularly fruitful to explore the role of feelings in the geographical and relational entanglements that we, in academia, call fieldwork. These moments are experienced by individuals, but they exist within specific historical and socio-political contexts. Through my empirical material, I connect various expressions of fatigue as they are articulated and circulated by different actors such as refugees, activists, aid workers and myself as researcher. Specifically, working with fatigue in the research setting of politicised migration debates in Europe requires active engagement with themes related to power dynamics and racialised hierarchies in knowledge production. Questions arise about who benefits from the researcher's attention, what narratives are clouded when focusing on certain communities and places as opposed to others, and what ideas of the Other are evoked in migration research? These questions are discussed at length in decolonial literature on migration (Aparna, 2020; Aparna, Kande, Kramsch, \& Schapendonk, in press; Bejarano, Juárez, García, \& Goldstein, 2019; Robbins, 2013; Vanyoro, Hadj-Abdou, \& Dempster, 2019), which investigates how new postcolonial configurations of the West that play out in the migration-control field and scholarship engaged with this field. I draw much inspiration from these approaches that attempt to expose the embedded power relations in the financial, historical and socio-political structures of academia that, e.g., create and maintain inequalities. Furthermore, decolonial scholars such as Aparna et al. (in press) argue for developing alternative ways of knowledge production, such as collaborative knowledge production and embodied research. Ahmed's theorisations of emotions tie in well with these decolonial works as they allow to address the relationality of emotions and how these are shaped in a socio-political space.

While Ahmed's theorisations of emotions provide the overarching theoretical framework, I bring in Ngai's (2005) notion of "ugly feelings" to hone in on the specificity of the emotion of fatigue. Ngai explores emotions such as irritation, anxiety or envy that are typically characterised "by a flatness or ongoingness" (Ngai, 2005, p. 7). These characteristics contrast those of other emotions marked by "suddenness" (Ngai, 2005, p. 7), such as anger or joy, which have received more attention in academia and literature. It is this absence of abruptness that allows ugly feelings to linger longer than those more sudden emotions. In my reading, fatigue too can be understood as an ugly feeling, smouldering quietly rather than burning hot and intensely. Fatigue may thus not be immediately visible and marked by a different temporality than the immediacy associated with sudden emotions such as joy and anger. As such, the ugly emotion of fatigue is of particular relevance for a reflexive engage- ment with the academic field of migration studies that is so often marked by notions of crisis and urgency.

Scene: On the train from Hamburg to Copenhagen, we stop in the borderlands between Germany and Denmark. Border police enters the train. An announcement over the speaker tells passengers to keep their documents handy for a passport check. I have seen this happen many times in the last years during my frequent travels between Copenhagen and Hamburg. In an attempt to make the border guards' jobs more difficult, I usually make a big deal of not having my passport ready and making them wait. However, this time, the police march immediately through the entire train compartment directly to a Black man sitting in a 4-person booth and two women of colour sitting on the other side of the isle from him. The police aggressively demand to see the man's passport. They ask: "Where are you going? What are you doing in Denmark?" The police's demeanour is intimidating. Once they seem to be done checking the man, they turn around and check the passports of the two women sitting across the aisle. Then they turn to leave to the next train compartment. Now I am furious. I spontaneously get out of my seat and walk up to the police, waving my German passport in my hand. "You haven't checked my passport yet," I say to the police officer standing nearest to me as I shove my passport towards him. He looks puzzled and barely glances at the document. "I thought you are doing a passport check?" I ask exasperatedly, hoping that my tone carries all the subtext I am trying to convey: "I see what you are doing, this is racial profiling, this is part of the Schengen area so why are you checking anyway." The police officer simply replies: "It's a random passport check." "Right...a random check," I answer trying to sound as sarcastic as possible as I turn and walk back to my seat. The other passengers are staring at me trying to figure out what is going on. My hands are shaking now, I am guessing from anger and adrenaline. As soon as I sit back down in my seat, doubts about my act creep up. I spend the rest of the train ride wondering if I did the right thing, if I acted in the interest of the people that were being checked, if I could have made the situation worse for them. I felt compelled to do something, but I don't know if it was the right thing to do.

I recount this event of racial profiling on the train here, not because there was anything unexpected or surprising about its occurrence (see, for example, Schwarz, 2016, who discusses similar events at the Italian-Swiss border); on the contrary, as I will show in the following sections, racial profiling by police is regrettably all too regular an occurrence for Black men in Germany (Bechtel, 2017; Belina, 2016). In this moment on the train, I was moved by fatigues that had accumulated in the previous days and weeks. When the border guards entered 
the train that day, I was tired, angry and sad. The incident happened on 20 February 2020, a day after I attended the memorial service for Yaya Djabi, a Gambian man who died in a German prison cell (see Section 4) and only hours after a right-wing extremist murdered nine people at a Shisha bar in a heinous racist attack in Hanau, Germany.

To me, the scene captures the entangled emotions with near- and far-histories of racialisation, police violence, citizenship and borderland geography. However, it also shows how far emotional spaces can reach into each other when the subject-positions are derived from a pervasive inequality within the emotional geography. The accumulative effect of fatigue(s) provoked my impulsive reaction to discrimination, which almost immediately became reflexive of the history of racialisation and current migration control policies that shaped the scene and my position in it. Writing explicitly about my own emotional relations to and in the field, and the ensuing insecurities, is uncomfortable, especially as most of my academic training up to this point has taught me to relegate my own emotions to a small section of the article, the predominant academic product, known as the "methods section." However, it enables reflection on how I, as a researcher, navigate those complicated experiences, relations and expectations and how they are shaped through encounters and differentially experienced histories. More importantly, however, by laying bare these fatigues and my discomfort, I can attempt to challenge the "one-way mirror" (Zuboff, 2019) that researchers often hold up to interlocutors without having to look into the mirror oneself. How much easier is it to explore another person's emotions in writing than addressing one's own? Yet, maybe being able to expose these discomforts can be an entry point into addressing the violence and uneven geographies in which 'the researcher' and 'the researched' move, as suggested by decolonial migration scholarship.

\section{Research Fatigue}

It was in Athens in early 2019, while participating in an academic workshop on migration in Greece, that I initially heard the term 'research fatigue' used by Greek scholars, activists and residents of informal squats. In the academic literature, research fatigue is understood as feelings of exhaustion and exasperation by communities and individuals who receive sustained attention from researchers, particularly social scientists, and yet have not felt any positive effects from this attention (see Clark, 2008; Sukarieh \& Tannock, 2013; Way, 2013).

I relate research fatigue to the temporality of crisis that has marked much of the developments in recent migration studies (Cabot, 2019; Rozakou, 2019; Tazzioli \& De Genova, 2016). In her article "The Business of Anthropology and the European Refugee Regime," anthropologist Heath Cabot (2019) poignantly argues that the portrayal of migration events in 2015-2016 must be understood as an instance of "crisis chasing," which she describes as "the propensity to take crisis as a driver of scholarship; assuming that 'refugee experiences' need to be studied; and, finally, heeding the call to 'do good' through scholarship in ways that deflect attention from anthropology's own politics of life" (Cabot, 2019, p. 262). It is this propensity for crisis-chasing that has marked much of the research on migration in the social sciences and humanities in recent years, and which raises questions about how, why and for whom this research is conducted. Having myself 'come-of-age' as a student in migration studies in 2015 , at precisely the moment when the topic took centre stage of public and political attention in Europe, has also informed my own trajectory as a researcher. My education and nascent career have thus been shaped by the omnipresence of crisis narratives and a resulting surge in academic funding for research on these issues (Cabot, 2019).

Scene: Lea, Charles, Anne and I are sitting in a café at Victoria Square with Poya, the young man we will interview. We are meeting Poya to talk with him about refugee squats in Athens. He is a resident of City Plaza, one of the most well-known squats in Europe these days. "Are you also anthropologists?" Poya asks, as we settled into our chairs and order our coffees. Some of us are anthropologists, some of us are not, but all of us are in some way working on themes of migration and mobility in Europe. It is obvious that Poya recognises 'our type.' Over the last few years, he has spoken to many researchers, mostly social scientists and journalists, people just like the four of us. Poya's ability to read and immediately place us in a larger socio-political and academic environment leaves me shifting uncomfortably in my seat. A mixture of embarrassment and guilt overcomes me as I am confronted with the fact that I too am part of the ever-growing group of, mostly Northern European, scholars travelling to Greece to conduct yet more research on 'the refugee experience.' My doubts about my role in this environment have been an underlying hum ever since I got a PhD position the previous year. But as I'm sitting across Poya in this café, it rings loudly in my ears.

It is Poya's recognition of 'us as anthropologists' that unsettles me in that moment at the café because it forces me to grapple with my own involvement in this dynamic of crisis-driven research that can engender research fatigue among those individuals and communities that feel no positive change to their circumstances, despite this persistent attention. A similar dynamic between research attention and fatigue also becomes apparent in the case of City Plaza.

In 2016, the former hotel, City Plaza, was squatted in by political activists and turned into a living space for up to 200 people, migrants and activists. City Plaza was radical, hopeful and simultaneously fraught with conflict- 
as might be suspected when utopian vision meets everyday reality (see, for example, Mezzadra, 2018; Raimondi, 2019; Squire, 2018). During City Plaza's early days, researchers and journalists were welcomed into the space and community. However, after years of sustained public attention and some harsh critiques, the residents decided not to open the space to researchers or journalists anymore. This decision remained in place until its closure mid-2019. The realities and imaginaries of City Plaza circulated far across the boundaries of the city in activist networks and international media (Crabapple, 2017; Donnerbauer, 2016). City Plaza became a "symbolic location" (Gilroy, 2013). It was a place that researchers flocked to in large numbers and it was the obvious entry point for us as 'newcomers' in Athens and therefore the reason that we were sitting in the café with Poya that afternoon.

Months after my initial meeting with Poya, I asked him how many times he had been interviewed by researchers in the last years. After a long pause, he replied that it must have been more than twenty times. Although I already knew that he had extensive experience with academics, I was nonetheless shocked to learn this. We, researchers, do not only seem to all flock to the same city, the same neighbourhood, and even the same building-City Plaza-but are we also all speaking to the same person in the course of our research? Rozakou (2019) argues that the amount of research into certain focal points such as the Moria refugee camp on Lesvos or City Plaza in Athens alone does not provide an in-depth picture. Rather, the amount of research can be indicative of the accessibility or enabling circumstances around the research production (Rozakou, 2019, p. 68). It raises questions about the quality of knowledge production itself when a symbolic location becomes central to a whole body of literature. However, it also exposes the constitutive elements of research fatigue in that it indicates the extractive propensities of knowledge production where empirical requirements for an academic output are often enabled and collected through a 'single point of access,' after which the 'knowledge-producer' moves on in the script.

While some individuals, such as Poya, and communities in Athens, such as City Plaza, were at the centre of academic interest, other communities and individuals, however, have not necessarily received similar attention:

Scene: Mamadou and $\mathrm{I}$ are sitting in his living room and are talking about political developments in Greece since early 2019. He tells me about how changes to the asylum procedures implemented by the new centre-right government a few months earlier have negatively affected him and his friends. Sometime into our conversation, his new-born child, who has been quietly sleeping next to Mamadou until now, starts to cry and won't be consoled even as Mamadou rocks the child in his arms while he walks around the living room. "I will give him a bath,"
Mamadou decides and beckons me to follow him to the bathroom. I lean against the doorframe as Mamadou lifts his child into a small basin and carefully pours water over the child's belly. It is the informality of that moment that makes me ask him something that has been burning on my mind since l've returned to Athens: "Are the questions I am asking relevant at all or am I missing something?" "The questions are fine," he says. "I like talking to people from other countries about these things. People should know what is happening to refugees here." It is then that he tells me that I am the first researcher whom he has spoken to about these topics in more than seven years that he has lived in Greece. After my conversations with Poya and all the talk of research fatigue that I've heard over the last months, I am surprised to learn this from Mamadou. I was almost certain that he, as the president of an African diaspora organisation, would have had a similar experience to Poya and been interviewed by researchers repeatedly.

I recall this moment here because, to me, it illustrates the contrast to Poya's experience and the symbolic location of City Plaza that are fatigued by the continued research attention and the lack of real change it has brought to their lives. Yet, what Mamadou expresses is a lack of attention from the 'outside' and a wish to actually be listened to. The examples of Poya and Mamadou highlight the uneven emotional landscape in which attention and inattention create different experiences of research fatigue. It strikes me that, in both instances, the men are enacting citizenship (Isin, 2009) and yet, in both instances, the resulting recognition of rights is never proportionate to the effort, regardless of where the crisischasing research is directed. The research attention may create moments of supposed representation (which in itself also raises questions about who is being represented, by whom and for whom), but it seems that research rarely amplifies the activist citizenship of refugees claiming their rights. Unequal distribution of attention, in other words, creates a similar result. Exhaustion can both arise in relation to continued attention by the research community without an experience of concrete, (positive) change and it can present itself in the frustrations experienced by people excluded from it. Moreover, even in documenting and taking notice of this exhaustion, I have to acknowledge my own role in its accumulation as a researcher entering a space that has been at the focal point of attention for the last several years.

\section{Racial Battle Fatigue}

In the following, I continue to elucidate how fatigue also takes shape as an emotional object through "histories of contact between racialised, gendered, sexualised, and otherwise differentiated bodies" (Laliberté \& Schurr, 2016, p. 74). This kind of fatigue is known as "racial battle fatigue," a concept coined by critical race theo- 
rist William Smith (2004). The term described the experiences of African American students and faculty at predominantly white universities in the United States and the responses in terms of psychological, bodily and social stress to racism in this institutional setting. Nowadays, the term is also applied to capture similar experiences by other racialised groups and individuals. Racial battle fatigue is closely linked to Hochschild's (2003) concept of emotional labour, referring to the work that racialised people have to do to exist and survive in white spaces and the adverse effects on mental and physical health (Smith, Yosso, \& Solórzano, 2011; Thorsen, 2018, 2019). Such racial battle fatigue unfolded in a specific fieldwork moment in Hamburg that spoke to the violence that young Black men experience in the city.

Scene: A group of 30-40 people are gathered in front of a white tent at Park Fiction to commemorate the fourth anniversary of the death of Yaya Djabi, a young man from Guinea-Bissau, who was arrested by police in Hamburg in 2016 for carrying 1.65 grams of marijuana. He spent several months in jail. Just a few days before his release, he was found dead in his cell. I attend the memorial in the cold and rainy Hamburg night and I recognise activists from migrant rights and anti-racist groups that I have met on other occasions. Tonight's memorial is organised by an umbrella initiative of different local anti-racist groups in the city. The initiative wants to officially re-name the square that the memorial is currently held in to 'Yaya Djabi Square.'

Yaya's friends and family speak about his death in a German prison, the lack of answers they have received since then, and the grief and anger they live with daily. A family member's voice grows loud$\mathrm{er}$, then trembles as he recounts that he was recently stopped by the police at the exact square that we are standing at now. How angry and upset it made him that the police officers didn't even know that this place is named after Yaya; that, until recently, there was a graffiti mural, a portrait of Yaya, on the building across the street. The speaker yells his anger and pain towards the police car parked in front of the square, presumably to keep an eye on the assembled group.

The pain and anger articulated in the above scene is an expression of racial battle fatigue, I argue, that is expressed most poignantly in the speeches of Yaya's friends and families. Here, racial battle fatigue is transformed into sudden, intense emotional expressions of, most prominently, anger and sorrow. This shows how emotions are knotted together in messy entanglements (Ahmed, 2014; Ngai, 2005); how the consistent brutality of racialisation produces states of fatigue alongside rage and sorrow.

In this moment of racial battle fatigue, I noted how the emotion circulates in a realm of historical and present-day lived trauma and violence. Moreover, it links to the violence of (in)attention as it relates the struggles of overlooked communities to the attention that certain refugee communities that arrived in Europe more recently receive. The above scene provides an insight into how when Black migrants in Europe do receive attention, it is most often in the form of violence through repressive policies and policing. This violence is also articulated in what has been referred to as the "politics of exhaustion" (Welander \& Vries, 2016) which is understood as political and institutionalised forms of violence through the migration control policies directed towards refugees. This violence is expressed through increasingly restrictive asylum procedures, a suspension of asylum decision-making, leaving people in states of limbo indefinitely, and camps such as the infamous Moria camp on Lesvos Island as well as deportation centres in which people are held in prison-like settings (see Davies, Isakjee, \& Dhesi, 2017; Suárez-Krabbe, Lindberg, \& Arce, 2018). Moreover, continuous racial profiling, as described previously, and other discriminatory practices contribute to this exhaustion even beyond the immediate sites of the migration spectacle such as borders and camps. As the scene above describes, these practices of exhaustion and violence extend themselves to European urban spaces. It is in the circulation of racialised histories, of state violence against Black people and especially Black migrants in Europe that racial battle fatigue moves and in which it accumulates with every violent encounter. Bringing the "politics of exhaustion" into conversation with experiences of racial battle fatigue is helpful in connecting these struggles, which occur in different countries and moments in time, but which are linked through the post-colonial configurations of the migration control field.

These racialised experiences of fatigue are pertinent in the example of Mamadou (see previous section) as well as the grievances voiced at the community meetings by different African diaspora associations that I attended in Athens. During these meetings, attendees repeatedly expressed feeling doubly marginalised, both as migrants, and as Black people. They felt excluded from Greek society, NGOs and humanitarian organisations as well as from other migrant communities. At one of these meetings, a participant remarked that African migrants were unable to attend many of the programs and support structures offered by NGOs and local initiatives because they focused on Arabic or Farsi-speaking refugees. These examples indicate a selectiveness of institutional (in)attention. The institutional (in)attention can give rise to a different kind of fatigue, which is produced when individuals and communities are continuously overlooked and excluded from services and participation. While symbolic locations such as City Plaza become illuminated through the bright spotlight of media and research attention, other communities existing in the shadows of this spotlight are exhausted from inattention. 
Mamadou and many members of his association arrived in Athens years before the summer of 2015. And although many are still struggling to get papers and against precarity, they are in other ways less 'novel' and, therefore, possibly of less interest to journalists and researchers. (In)attention is related to the temporal properties of immediacy or lack thereof. As the events of 2015 were framed as immediacies and crises by politicians, the public and researchers, the experiences of people who had arrived in Athens previously were not included in the urgency paradigm (Tazzioli \& De Genova, 2016).

Although in a very different manner, the fatigue and exhaustion produced by border violence and restrictive migration policies also affects people working in the field as it impedes their ability to support and struggle with the migrant communities targeted by these policies.

\section{Compassion Fatigue}

Scene: Alexandros quit his previous job in Thessaloniki, where he worked with homeless undocumented youth, because of his grievances with the limited resources available: Building trust relationships with the youth was a long and tedious process and once he finally established trust, Alexandros felt he could not offer much to the young people. Youth shelters were overcrowded and the social workers could not create housing alternatives, let alone provide psychological support. He left the job, moved to Athens and now works as a psychological counsellor at a shelter for 300 asylum seekers. Most of the people living there have chronic illnesses and mental health issues. They usually live there for two to three months. In this time, they see many different counsellors and social workers and often have to retell their traumatic experiences to new personnel without access to long-term therapeutic treatment. Alexandros describes the situation in drastic terms, saying "the people are treated like animals in an experiment." He knows that the conditions of his work are terrible, but he continues to do the best he can with the limited means available. Nonetheless, Alexandros is unsure how long he will be able to continue working in this field. The circumstances are taking a toll on him.

Alexandros's fatigue is not a singular emotion, but an amalgam of knotted feelings (Ngai, 2005), including, among others, frustration and feeling responsible to ensure access to legal and social support services for migrants in the country. His fatigue was mirrored in conversations I had with other social workers who discussed similar challenges. One woman, referring to changes to the asylum procedure implemented by the Greek government in mid-2019, summarised this sentiment when she said: "I feel like we are back to square one." In these examples, fatigue circulates between social workers and researchers who work within the domain of asylum and migration, and the refugee bodies onto which the disciplinary tools of bureaucratic and administrative practices are impressed, and, in turn, reflected, rejected and contested. Social workers expressed the pain and frustration that they experienced working in a political context that continuously restricted their professional capability to adequately support the people they work with. Their fatigue circulates in the politicised realm of restrictive EU migration and asylum policies in which deterrence at the borders and deportation policies increasingly replace protection and rights-based approaches.

The term 'compassion fatigue,' frequently used in the context of health care and social work, describes the emotions experienced and the eventual emotional flattening which practitioners, who repeatedly hear and witness others' trauma in their work, may experience (Fox, 2019). The repetition of trauma in their work can erode practitioners' ability to remain compassionate as a result of numbing to others' trauma, such as instances where a general sense of fatigue results in disengagement and cynicism (see Eule, Borrelli, Lindberg, \& Wyss, 2019; Wettergren, 2010). Alexandros's story, however, elucidates a further nuance to compassion fatigue. In this case, it is the severity of the trauma witnessed in daily work combined with a sense of helplessness in relieving these traumas with the tools and institutional context available to him as a social worker that evokes his fatigue. In other words, compassion does not fatigue, but the inability to act creates fatigue. Hofmeyer, Kennedy, and Taylor (2019) thus propose the concept of 'emphatic distress fatigue' to more accurately address this experience. This concept, I also want to suggest, captures Alexandros's experience more succinctly. Empathic distress fatigue is not limited to those in professional care capacities. Because fatigue circulates between, amongst others, different institutional agents, it is also felt among researchers who are entangled in this circulation (see also findings by Welander \& Vries, 2016).

Scene: Since arriving in Hamburg a few days ago, I have felt anxious and tired. I should be leaving the house, meeting people, reaching out to NGOs and migrant organisations and catching up with interlocutors from a previous project, but I can't. I have barely left the house for two days. I don't want to speak to anyone. I postpone my meeting with Navid, an interlocutor, only to feel regretful of that decision moments later. After all, he is doing me a favour by agreeing to meet up. Am I a resource, a disturbance or even an imposition, and does he want to meet out of a feeling of obligation? What if he doesn't want to meet me anymore?

In the above scenes, fatigue "ripples" (Ahmed, 2014, p. 120) and spills over to others entangled with the migration field, such as Alexandros, and eventually myself in the role of researcher. In the scene, my own position as a node within this network of fatigue became 
apparent while I simultaneously struggled to comprehend its meaning. However, while I too experience a kind of fatigue by the complexities of the migration field in Hamburg, as a researcher, I can withdraw from the field and, to some extent, the emotionality associated with it. This sets me apart from most of the interlocutors in my research and reveals the uneven emotional geography in which fatigues impress on bodies and realities. As Laliberté and Schurr (2016, p. 75) argue: "Our fluctuating emotional geographies during research are produced through processes of identification and disidentification emerging and unfolding in different spatial and temporal contexts of the field." Writing about my own fatigue in relation to the fatigues experienced by others within the affective economy reveals the reach, legitimacy and possibilities of different emotional spaces. It points towards different modes of expression and ways of addressing the objects of fatigue, which are interrelated through colonial histories and post-colonial presents. Fatigue, in the examples of Alexandros and myself, has the power to alienate us from our 'fields' as we struggle to understand our place in it, but it can also lead us to ask how we can position ourselves within or against these dynamics. As Ngai (2005) shows, fatigue smoulders for a long time before it either dies down or erupts. Thus, if not addressed, fatigue may have the power to prevent solidarity and engagement by eroding feelings of connectedness and engagement. However, I wonder if, in a similar vein, fatigue may not also be a productive and creative force. How can we use, and at times even provoke an eruption of fatigue, to constitute empathic engagement between actors despite and because of their differentiated positionalities within the migration field?

\section{Concluding Remarks}

Fatigue, this 'ugly', slowly accumulating emotion (Ngai, 2005), circulates in the borderlands between Denmark and Germany, in the stories between Hamburg and Athens, between, with and through people like Poya, Mamadou, Alexandros, Yaya's friends and family, Navid and myself, through our lived experiences, our histories and the different institutional and social contexts. This is what Ahmed calls "the rippling effects of emotions" (2014, p. 120).

While I have tried to show how different fatigues emerged in my research encounters, I have also shown that all too often they are intertwined with other emotions and cannot be neatly separated into distinct types. The fatigues discussed here are interlinked across personal histories of racialisation, gender, class, citizenship and geography and exist in the realm of (and struggle against) an increasingly restrictive migration control field. These explorations of emotions render visible how fatigue is produced and shared, but also differently experienced by actors in in the field. Fatigue accumulates in the emotional geographies and through attachments formed in my fieldwork.
I hope this article has shown that using feelings such as fatigue as a methodologically tool and an analytical object in ethnographic accounts can open up for a reflexive engagement with the uneven emotional geographies that researchers move in, and that they in turn also shape. A critical engagement with the emotional entanglements through reflexive methods can uncover the uneven power relations at play in the relational geographies that researchers are part of (Aparna, 2020) and point towards some of the breaches between what research aims to do and the effects it has. It can be a useful starting point for calling into question the very hierarchies of knowledge production in which I, as a universityemployed $\mathrm{PhD}$ candidate, am embedded in. Moreover, this approach helps, not only in understanding our own positions in the fields that we as researchers are embedded in, but also how these positions are entangled with the much wider migration control field and the different actors involved in it. Together, we are co-producing the emotional geography of the field, even if as researchers we often have the possibility to withdraw again when our 'projects' are done.

\section{Acknowledgments}

I want to thank the two anonymous reviewers for their excellent comments. For their help with developing my thoughts on the role of emotions in fieldwork, I thank the editors of this thematic issue as well as Annika Lindberg and August Schwensen. This article is partly based on Mirjam Wajsberg' Research Talent Grant financed by Netherlands Organisation for Scientific Research (NWO), grant number 406.18.520.

\section{Conflict of Interests}

The author declares no conflict of interests.

\section{References}

Ahmed, S. (2014). The cultural politics of emotion (2nd ed.). Edinburgh: Edinburgh University Press.

Aparna, K. (2020). Enacting asylum university: Politics of research encounters and (re)producing borders in asylum relations. Nijmegen: Radboud University.

Aparna, K., Kande, O., Kramsch, O., \& Schapendonk, J. (in press). L'Europe n'est plus L'Europe: Montaging borderlands of help for a radical politics of place. Nordic Journal of Migration Research.

Bechtel, W. (2017). The state of racial justice in Germany. In M. Elósegui \& C. Hermida (Eds.), Racial justice, policies and courts' legal reasoning in Europe (pp. 157-166). Cham: Springer International Publishing.

Bejarano, C. A., Juárez, L. L., García, M. A. M., \& Goldstein, D. M. (2019). Decolonizing ethnography: Undocumented immigrants and new directions in social science. Durham, NC: Duke University Press.

Belina, B. (2016). Der Alltag der Anderen: Racial profil- 
ing in Deutschland? [The everyday life of the others: Racial profiling in Germany?]. In B. Dollinger \& H. Schmidt-Semisch (Eds.), Sicherer Alltag? Politiken und Mechanismen der Sicherheitskonstruktion im Alltag [Safe everyday life? Policies and mechanisms of security construction in everyday life] (pp. 123-146). Wiesbaden: Springer Fachmedien Wiesbaden.

Berlant, L. G. (Ed.). (2004). Compassion: The culture and politics of an emotion. New York, NY: Routledge.

Bondi, L. (2005). Making connections and thinking through emotions: Between geography and psychotherapy. Transactions of the Institute of British Geographers, 30(4), 433-448. https://doi.org/ 10.1111/j.1475-5661.2005.00183.x

Cabot, H. (2019). The business of anthropology and the European refugee regime. American Ethnologist, 46(3), 261-275. https://doi.org/10.1111/amet. 12791

Cantat, C. (2016). Rethinking mobilities: Solidarity and migrant struggles beyond narratives of crisis. Intersections. East European Journal of Society and Politics, 2(4). https://doi.org/10.17356/ieejsp.v2i4.286

Clark, T. (2008). 'We're over-researched here!' Exploring accounts of research fatigue within qualitative research engagements. Sociology, 42(5), 953-970.

Crabapple, M. (2017, June 23). This refugee squat represents the best and worst of humanity. The Guardian. Retrieved from https://www.theguardian.com/ commentisfree/2017/jun/23/refugee-squat-cityplaza-greece-best-worst-humanity

Davies, T., Isakjee, A., \& Dhesi, S. (2017). Violent inaction: The necropolitical experience of refugees in Europe. Antipode, 49(5), 1263-1284. https://doi. org/10.1111/anti.12325

Donnerbauer, P. (2016, June 5). City Plaza: Das RefugeeHotel im Herzen von Athen [City Plaza: The refugee hotel in the heart of Athens]. Vice. Retrieved from https://www.vice.com/de/article/vdjwwx/cityplaza-das-refugee-hotel-im-herzen-von-athen-123

Eule, T., Borrelli, L. M., Lindberg, A., \& Wyss, A. (2019). Migrants before the law: Contested migration control in Europe. Basingstoke: Palgrave Macmillan.

Fox, M. (2019). Compassion fatigue and vicarious trauma in everyday hospital social work: A personal narrative of practitioner-researcher identity transition. Social Sciences, 8(313). https://doi.org/ 10.3390/socsci8110313

Gilroy, P. (2013). There ain't no black in the Union Jack: The cultural politics of race and nation. London: Routledge.

Gorton, K. (2007). Theorizing emotion and affect: Feminist engagements. Feminist Theory, 8(3), 333-348. https://doi.org/10.1177\%2F1464700107082369

Hänsel, V., Hess, S., \& Kasparek, B. (2019). Border management and migration controls: Germany report (Paper 2019/21). Göttingen: Georg-August Universität. https://doi.org/10.5281/zenodo.3268245

Hochschild, A. R. (2003). The managed heart: Commer- cialization of human feeling (2nd ed.). Berkeley, CA: University of California Press.

Hockey, R. (2013). The psychology of fatigue: Work, effort and control. Cambridge: Cambridge University Press.

Hofmeyer, A., Kennedy, K., \& Taylor, R. (2019). Contesting the term 'compassion fatigue': Integrating findings from social neuroscience and self-care research. Collegian, 27(2), 232-237. https://doi.org/10.1016/ j.colegn.2019.07.001

Isin, E. (2009). Citizenship in flux: The figure of the activist citizen. Subjectivity, 29(1), 367-388.

Laliberté, N., \& Schurr, C. (2016). Introduction: The stickiness of emotions in the field-Complicating feminist methodologies. Gender, Place and Culture, 23(1), 72-78. https://doi.org/10.1080/0966369X. 2014.992117

Lutz, C., \& Abu-Lughod, L. (Eds.). (1990). Language and the politics of emotion. Cambridge: Cambridge University Press.

Mezzadra, S. (2018). In the wake of the Greek Spring and the Summer of Migration. The South Atlantic Quarterly, 117(3), 925-933. https://doi.org/10.1215/ 00382876-7166092

Ngai, S. (2005). Ugly feelings. London and Cambridge, MA: Harvard University Press.

Raimondi, V. (2019). For 'common struggles of migrants and locals.' Migrant activism and squatting in Athens. Citizenship Studies, 23(6), 559-576. https://doi.org/ 10.1080/13621025.2019.1634373

Robbins, J. (2013). Beyond the suffering subject: Toward an anthropology of the good. Journal of the Royal Anthropological Institute, 19(3), 447-462. https:// doi.org/10.1111/1467-9655.12044

Rozakou, K. (2019). 'How did you get in?' Research access and sovereign power during the 'migration crisis' in Greece. Social Anthropology, 27(S1), 68-83. https:// doi.org/10.1111/1469-8676.12620

Rozakou, K. (2020). Crisis. In A. D. Lauri (Ed.), Humanitarianism: Keywords (pp. 38-40). Leiden and Boston, MA: Brill.

Schmitz, S., \& Ahmed, S. (2014). Affect/emotion: Orientation matters-A conversation between Sigrid Schmitz and Sara Ahmed. Freiburger Zeitschrift für Geschlechter Studien, 22(2), 97-108. https://doi.org/ 10.3224/fzg.v20i2.17137

Schwarz, I. (2016). Racializing freedom of movement in Europe: Experiences of racial profiling at European borders and beyond. Movements. Journal for Critical Migration and Border Regime Studies, 2(1), 255-265.

Smith, W. (2004). Black faculty coping with racial battle fatigue: The campus racial climate in a post-civil rights era. In D. Cleveland (Ed.), A long way to go: Conversations about race by African American faculty and graduate students (4 ed., pp. 171-190). New York, NY: P. Lang.

Smith, W. A., Yosso, T. J., \& Solórzano, D. G. (2011). Challenging racial battle fatigue on historically white campuses: A critical race examination of race-related 
stress. In R. D. Coates (Ed.), Covert racism: Theories, institutions, and experiences (pp. 211-237). Leiden: Brill.

Squire, V. (2018). Mobile solidarities and precariousness at City Plaza: Beyond vulnerable and disposable lives. Studies in Social Justice, 12(1), 111-132. https://doi. org/10.26522/ssj.v12i1.1592

Suárez-Krabbe, J., Lindberg, A., \& Arce, J. (2018). Stop killing us slowly: A research report on the motivation enhancement measures and criminalization of rejected asylum seekers in Denmark. Copenhagen: Roskilde University.

Sukarieh, M., \& Tannock, S. (2013). On the problem of over-researched communities: The case of the Shatila Palestinian refugee camp in Lebanon. Sociology, 47(3), 494-508. https://doi.org/10.1177\% 2F0038038512448567

Tazzioli, M., \& De Genova, N. (Eds.). (2016). Europe/crisis: New keywords of "the crisis" in and of "Europe." New York, NY: Zone Books.

Tazzioli, M., \& Garelli, G. (2018). Containment beyond detention: The hotspot system and disrupted migration movements across Europe. Environment and Planning D: Society and Space and Polity. Advance online publication. https://doi.org/10.1177 $\% 2 F 0263775818759335$

Thorsen, T. S. (2018, May 20). Denmark's racist backlash: On battle fatigue across borders. Tess S. Skadegard Thorsen. Retrieved from https://medium. com/@tess_thorsen/denmarks-racist-backlashc6cbdc8e5e53

\section{About the Author}

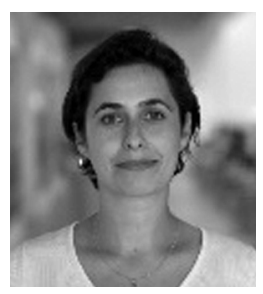

Mirjam Wajsberg is a PhD Candidate at the Department of Geography, Planning and Environment at Radboud University (NL). Her PhD project takes place between Germany, Denmark and Greece and focuses on im/mobility trajectories of refugees in the EU and different forms of urban resistance to EU migration policies.
Thorsen, T. S. (2019). Minoritetsbeskatning-et værktøj til at forstå opretholdelse af strukturelle uligheder i dansk akademia. [Minority taxation-A tool for understanding the maintenance of structural inequality in Danish academia]. Kvinder, Køn \& Forskning, 28(1/2), 31-43.

Vanyoro, K. P., Hadj-Abdou, L., \& Dempster, H. (2019, July 19). Migration studies: From dehumanising to decolonising. LSE Higher Education Blog. Retrieved from https://blogs.Ise.ac.uk/highereducation/2019/ 07/19/migration-studies-from-dehumanising-todecolonising

Way, E. (2013). Understanding research fatigue in the context of community-university relations (Unpublished Master's dissertation). Clark University, Worcester, Massachusetts, USA. Retrieved from https://commons.clarku.edu/cgi/viewcontent.cgi? article $=1018 \&$ context $=$ localknowledge

Welander, M., \& Vries, L. A. d. (2016, September 30). Refugees, displacement, and the European 'politics of exhaustion.' openDemocracy. Retrieved from https://www.opendemocracy.net/en/mediterraneanjourneys-in-hope/refugees-displacement-and-europ

Wettergren, A. (2010). Managing unlawful feelings: The emotional regime of the Swedish migration board. International Journal of Work Organisation and Emotion, 3(4). https://doi.org/10.1504/IJWOE.2010. 035327

Zuboff, S. (2019). The age of surveillance capitalism. London: Profile Books. 